\title{
RELATIONSHIPS BETWEEN POCKET GOPHER NUMBERS AND SELECTED ENVIRONMENTAL FACTORS IN PELICAN VALLEY, YELLOWSTONE NATIONAL PARK
}

\author{
Clifton C. Youmans \\ Biology Department \\ Montana State University
}

This report concerns the current investigation of effects of selected environmental factors on numbers of pocket gophers (Thomomys talpoides) in Pelican Valley, Yellowstone National Park, Wyoming. The study is being supported by the University of Wyoming/National Park Service Research Center. I wish to express my appreciation to the following individuals for their contributions to the study: Dr. Robert Moore, Montana State University, who directed the study and aided in the preparation of this report; Drs. Gerald $\mathrm{Nielson}, \mathrm{Cl} i f f o r d$ Montagne and Lawrence Munn, Montana State University, for aid in classification and analysis of soils from the study area; Dr. Theodore Weaver, Montana State University, for aid in analysis of vegetation data; Dr. John Taylor and Mr. Wayne Leininger, Montana State University, for assistance with aerial photography techniques; Mr. Roger Rudolph, Subdistrict Ranger, for his cooperation.

\section{Study Objectives}

A. Estimate numbers and seasonal burrowing activity of pocket gophers on representative sites in Pelican Valley.

B. Estimate times of reproductive activity, particularly the period of nursing of young.

C. Measure the following environmental factors at representative sites: snow depth, soil water table, depth of $A_{1}$ layer and organic matter content, soil texture, depth of soil available for burrowing by pocket gophers, and soil moisture.

D. Quantitatively measure herbaceous vegetation at representative sites.

\section{Methods}

Eight belt transects $100 \mathrm{~m}$ long and $10 \mathrm{~m}$ wide were established during the summer of 1977. One additional belt transect of the same dimensions was established in June of 1978. These nine belt transects served as the primary sites of data collection during the 1978 field season. Belt transects were established on sites considered to be most representative of existing plant communities and soil types in Pelican Valley. 
Relative indices of pocket gopher numbers during snow-free months were made through the use of mound counts (Reid et al. 1966).

Two belt transects were intensively trapped during September of 1978 by using Macabee death traps in an attempt to collect pocket gophers live-trapped, marked, and released during the pervious year's field season. Numbers of individuals collected on the two belt transects combined with mound count data obtained immediately prior to trapping allowed for computation of the number of mounds built per pocket gopher per 48-hour time interval. Data on sex ratios, age structure, home range size, mortality/natality rates were obtained and are being analyzed.

A total of 300 pocket gophers were collected both from belt transects and other sites with similar vegetation and soils during the course of the study. Determination of reproductive status and number of placental scars in females of breeding age will be accomplished. Tryon (1947), found that after partus, placental scars are left in the uterus and are distinct enough to count and determine the number of young born.

Relative numbers of pocket gophers during periods of snow cover on eight of nine belt transects were indexed. Centimeters of winter soil casts intercepted along line transects in June after snow melt were recorded. Richens (1965) reported a significant correlation between the number of casts per acre and the population index for his study area.

The vegetation on the nine belt transects was quantitatively measured. Scientific and common names of plants follow Booth (1950) and Booth and Wright (1959). Composition and canopy coverage of low growing vegetation on each of the nine transects were determined from a modification of the method described by Daubenmire (1959). Twenty-five $2 \times 5$ decimeter plots were placed at four meter intervals along the center line of each transect during the 1978 field season. Canopy coverage data for two field seasons were obtained.

Line intercepts coinciding with the center line of each of the $\mathrm{nine}$ belt transects were used to quantitatively measure abundance of yampa (Perideridia gairdneri) and purple oniongrass (Melica spectabilis) for the month of August in both 1977 and 1978.

Data on standing crop for the month of August were obtained on the nine belt transects by clip plots. Two of the nine belt transects were intensively sampled using 10 circular clip plots, each equal to $9.6 \mathrm{ft}^{2}$. The remaining seven belt transects were sampled using 10 circular clip plots each equal to $0.96 \mathrm{ft}^{2}$. On all nine belt transects a stratified random sampling scheme determined the location of clip plots. Belt transects were partitioned into sections equal to $10 \mathrm{~m}^{2}$ along their lengths. One clip plot was randomly selected within each $10 \mathrm{~m}^{2}$ section of the belt transects. Plant species clipped from each plot were bagged separately. Some species cccurring only infrequently were lumped together.

Soil samples were collected monthly from each of the nine belt transects at the $25 \mathrm{~m}$ and the $75 \mathrm{~m}$ marks. Soil samples from zero to four inches in depth, 
and from four to 12 inches in depth were collected at these two intervals with an Oakfield Apparatus. Samples from each depth at each interval were placed in Whirl Pac bags and weighed upon return from the field. Soils were subsequently oven dried and weighed again to obtain a relative index of moisture. Mechanical analysis of soil follows procedures outlined by Sims (1970).

An attempt to relate pocket gopher tolerance to percent water saturation of soil was made. Three line transects were established between two belt transects separated by a low sedge meadow. Monthly soil samples were taken at five meter intervals along these three line transects at depths of zero to four inches and four to 12 inches. Comparison between oven dried soil weights and field weights allowed for computation of approximate percent saturation of water for each sampling period. Presence of pocket gopher mounds along the line transects were recorded simultaneously with monthly soil samples.

Aerial photography missions were flown using a Piper Supercub aircraft on April 28 and October 8 of 1977 and June 1 of 1978. Snow melt phenology was recorded in Pelican Valley during the April, 1977 and June, $1978 \mathrm{flights.}$ During the October, $1977 \mathrm{flight,}$ an attempt was made to census pocket gopher mounds using aerial photography. Driscoll and Watson (1974) found that photointerpretation of 1:600 scale color infrared aerial photographs for fresh pocket gopher mounts allowed for estimates of pocket gopher populations 97 percent as accurate as estimates derived from ground inventory.

Results and Discussion

The two major habitat types represented on the nine belt transects were classified according to Mueggler and Handl (1974). Festuca idahoensis/ Deschampsia caespitosa and Festuca idahoensis/Stipa occidentalis were determined to be the two habitat types, using the above criteria. It is the opinion of this investigator that the percent cover by Artemisia cana is great enough to use the artitrary type Artemisia cana/Festuca idahoensis in lieu of Festuca idahoensis/Stipa occidentalis.

A total of 38 pocket gophers were captured, marked and released on two adjacent belt transects during the 1977 field season. These two belt transects represented the two different habitat types. Of the 21 pocket gophers that were marked and released from the Festuca idahoensis/Deschampsia caespitosa habitat type, five were collected during the $1978 \mathrm{fiel} d$ season. of the 17 pocket gophers that were marked and released from the Artemisia cana/Festuca idahoensis habitat type, four were collected during the 1978 field season.

During the two field seasons a total of 300 pocket gophers were collected from representative sites throughout Pelican Valley. Sex ratios of pocket gophers collected during July of 1977 were equal. This ratio suggests that females were equally susceptible to trapping at this time and thus were 
probably not nursing. Data on sex ratios for pocket gophers collected throughout the 1978 field season are still being analyzed. Hansen (1960) found that in the spring the sex ratio showed a higher percentage of males than females. This was attributed to females being less vulnerable to traps due to pregnancy, parturition, and post natal care of young.

Reproductive tracts from female pocket gophers collected during the 1978 field season have not yet been analyzed. Data obtained from the previous field season suggest differences in mean scar counts between pocket gophers collected from the two habitat types.

Pocket gopher numbers were indexed throughout the summer months by utilizing mound counts. Mound counts were found to be lowest in the spring and to increase throughout the summer months. Highest mound counts were obtained in late August and early September for both years. Laycock (1957) and Miller and Bond (1960) found mound-building activity increased from spring to fall.

Centimeters of winter soil casts intercepted along line transects in June were used to index pocket gopher numbers during periods of snow cover. Correlation between total centimeters of soil casts intercepted per transect in June of 1978 and mound counts made in July of 1977 were significant.

Preliminary examination of mound count data from sites also kill-trapped in September of 1978 suggests that nearly twice as many mounds were built per pocket gopher on the Festuca idahoensis/Deschampsia caespitosa belt transect as were built per pocket gopher on the Artemisa cana/Festuca idahoensis belt transect.

Mean canopy coverage per species for all transects in both 1977 and 1978 was computed. Canopy coverage data are being analyzed for possible correlation with mound count data. Preliminary computations suggest that several plant species are significantly correlated with pocket gopher mound counts.

Correlations of pounds per acre of several plant species with mound counts have been accomplished. Significant correlation coefficients were obtained between pounds per acre of narrow leaved collomia (Collomia linearis), purple oniongrass, Idaho fescue, and needlegrass (stipa occidentalis).

Combined line intercepts of both yampa and purple oniongrass correlated significantly with mound counts, yielding correlation coefficients of 0.82 and 0.83 for 1977 and 1978 , respectively.

Mechanical analysis of soil samples from the eight study transects established in 1977 have been accomplished. All soil samples from these transects fall into the category of 'silt loams'. Data on soil moisture and pocket gopher tolerance to soil moisture are still being analyzed. Preliminary data suggest pocket gophers are typically absent from soils of a heavy clay loam texture. The soil profile for which pocket gopher activity is typically present is a loamy to sandy loam textured soil. 
Aerial photography of the study area revealed that the snow melt phenology of the study area in 1978 was fully three weeks later than that of 1977. Attempts to census pocket gopher numbers through the use of aerial photography proved largely unsuccessful. High winds and the varying presence of sunlight hampered attempts to obtain at least 60 percent overlap for stereo interpretation of photographs and minimum exposures.

\section{Recommendations and/or Conclusions}

Specific soil and vegetation characteristics appear to determine pocket gopher numbers and distribution in Pelican Valley. Forage species which have thus far been positively correlated with pocket gopher densities either increase productivity of pocket gophers or share similar ecological requirements. Further data analysis will hopefully illuminate these and other interrelationships between pocket gophers and environmental factors.

A final report will be submitted as a Masters thesis from Montana State University.

\section{Literature Cited}

Booth, W. E. 1950, Flora of Mnntana--Part 1, Conifers and Monocots. Res. Found., Montana State College, Bozeman. 232 pp. and J. C. Wright. 1959. Flora of Montana--Part 11, Dicotyledons. Montana State College, Bozeman. $280 \mathrm{pp}$.

Daubenmire, R, F. 1959. A canopy-coverage method of vegetational analysis. Northwest Science. 33(1):43-64.

Driscoll, Richard S. and Thomas C. Watson. 1974. Aerial photography for pocket gopher populations. In Proc. Symp. Remote Sensing and Photo Interpretation (Banff, Alberta, Can., Oct. 1974) Int. Soc. Photogramm. Comm. V11, vol. 2, Can. Inst. Surveying, Ottawa, Ont. 481-492.

Hansen, R. M. 1960, Age and reproductive characteristics of mountain pocket gophers in Colorado. J. Mammal. 41(3):323-335.

Laycock, W. A. 1957. Seasonal periods of surface inactivity of the pocket gopher. J. Mammal. 38(1):132-133.

Miller, R. S. and H. E. Bond. 1960. The summer burrowing activity of pocket gophers. J. Mammal. 41(4):469-475.

Mueggler, W. F. and W. P. Handl. 1974. Mountain grassland and shrubland habitat types of western Montana. U.S.D.A. Forest Service. Intermountain Forest and Range Experiment Station and Region 1. 89 pp. 
Reid, V. H., R. M. Hansen, and A. L. Ward. 1966. Counting mounds and earthplugs to census mountain pocket gophers. J. Wildl. Manage. 30(2): 327-334.

Richens, V. V. 1965. An evaluation of control on the Wasatch pocket gopher. J. Wildl. Manage. 29(3):413-425.

Sims, J. R. 1970. A Guide to Laboratory Experiences in Soil Science. Chaff and Dust Club, Montana State University, Bozeman. 56 pp.

Tryon, C. S., Jr. 1947. The biology of the pocket gopher (Thomomys talpoides) in Montana. Mont. State Coll. Agr. Exp. Sta. Tech. Bull. 448. $30 \mathrm{pp}$. 